\title{
Ralstonia solanacearum the Causal Agent of Ginger Bacterial Wilt - A Review
}

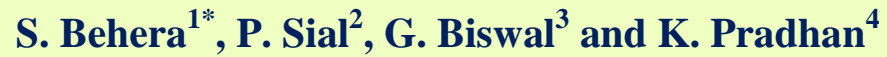

${ }^{1}$ Plant Pathology, ${ }^{2}$ Plant breeding and genetics, High Altitude Research Station (O.U.A.T), Pottangi, Koraput, Odisha, India

${ }^{3}$ Department of Plant Pathology, College of Agriculture, O.U.A.T., Bhubaneswar, Odisha, India

${ }^{4}$ Associate Director of Research (ADR), Regional Research and Technology Transfer Station, Odisha University of Agriculture \& Technology, Semiliguda, Koraput, Odisha, India

*Corresponding author

\section{A B S T R A C T}

Keywords

Ralstonia

solanacearum, Ginger

Article Info

Accepted:

18 November 2020

Available Online:

10 December 2020
Bacterial wilt caused by Ralstonia solanacearum is a serious threat for ginger production worldwide. Among different biovars of it, biovar III race 4 found to be most destructive. This study was focused on bacterial wilt of ginger with special reference to pathogen biology, mode of infection, epidemiology, disease symptoms, host pathogen interaction and its economic importance.

\section{Introduction}

Ginger (Zingiber officinale Roscoe) an herbaceous perennial plant mainly used as spice and flavor agent for food. Due to the presence of volatile oils consisting of Zingerone, shogaols and gingerols, ginger got its characteristic fragrance and flavor. Ginger rhizome which is the consumed portion is the horizontal stem of the plant that sends out the roots. Due to the attack of various pathogenic diseases of viral, bacterial, fungal and nematode origin, yield of the ginger reduced drastically. Among the various diseases, Soft rot, Bacterial wilt, Phyllosticta leaf spot, Mosaic and Chlorotic flecks are important. Bacterial wilt is one $\mathrm{f}$ the most destructive disease of ginger caused by Ralstonia solanacearum previously known as Pseudomonas solanacearum (16) is the causal agent of bacterial wilt which belongs to the Proteobacteria, $\beta$ subdivision, Ralstonia group and the genus Ralstonia reported from all the ginger growing countries. Bacterial wilt of ginger, also known as "ginger blast" or "Mahali"/ "green wilt" caused by Ralstonia 
pseudosolanacearum (10) formerly Ralstonia solanacearum. Due to wide host range and long term survival ability in soil, it is very difficult to manage the disease completely. A brief knowledge of pathogen, its mode of infection, host range, pathogen survival, disease symptoms, host pathogen interaction is needed to generate a suitable management strategy.

\section{Causal organism}

Ralstonia solanacearum grouped into Kingdom: Bacteria, Phlum: Proteobacteria, Class: Beta proteobacteria, Order: Burkholderiales, Family: Burkholderiacaea, Genus: Ralstonia, Species: Solanacearum (24). Erwin F. Smith first described R. solanacearum in 1896 as Bacillus solanacearum and transferred it under genus Pseudomonas in 1914. (Fates and Impacts of the Genetically Modified Plant GrowthPromoting Bacterium Pseudomonas fluorescens, 1Lotta Jäderlund). Again it has been transferred to Burkholderia, first, then to Ralstonia (25). Thomas reported bacterial wilt of ginger in 1941 for the first time from India.(1). $R$. solanacearum is a Gram negative, aerobic non-spore forming, noncapsulated, and nitrate-reducing, ammoniaforming, aerobic, rod-shaped bacterium with polar flagella. (26). As per the host ranges and geographic distributions Ralstonia solanacearum $(R S)$ grouped into five races.

Race 1 attacks Bananas, Race 2 ornamental plants, Race 3 potato, Race 4 Ginger and Race 5 mulberries (8). Different biovars of Ralstonia solanacearum is named on the base of biochemical tests. Based on the ability to use or oxidize several hexose alcohols and disaccharides $R$. solanacearum is classified into five biovars, biovar I, II, III, IV and V.(5,23). Differentiation of R.solanacearum into 5 different biovars based in their ability to produce acid from three disaccharides (maltose, lactose and cellobiose) and oxidize three hexose alcohols (Mannitol, Sorbitol and Dulcitol) $(5,15,36)$. From various reports by Hayward (1964), Heet et al., (1 983) and Kumar and Sharma (2004), biovar III oxidizes both disaccharides and hexose alcohols where as biovar I oxidize hexose alcohols but not disaccharides, biovar II oxidizes only disaccharides and biovar IV oxidizes only alcohols.(3,11,12). As per Pegg and Moffett both biovar III and IV of Ralstonia solanacearum can attack ginger but in Australia biovar IV were highly virulent and destructive, it may be due to cool climate of Australia.(37).Under Indian climatic condition when biovar III has inoculated artificially in stem rapid wilt in ginger has been observed within 5 to 7 days after infection and 7 to 10 days under soil inoculation of pathogen. (4). Cook 1989 used Restriction fragment length polymorphism (RFLP) to study the relationship of $R$. solanacearum strains representing the three races and five biovars. As per the physiological properties they share a common character such as chemo organotrophic nutrition, aerobic metabolism, absence of fermentation, absence of photosynthesis, inability to fix nitrogen and capacity for growth on a large amount of organic substrates. Ralstonia species bear similar phylogeny and chemotaxonomic properties but they are different in pathogenicity, host relationship and other phenotypic properties.(9)

\section{Disease cycle and epidemiology}

Being a soil borne pathogen Ralstonia solanacearum infects roots by invading and multiplying in the xylem vessels. After penetrating the xylem vessels the bacteria produces certain enzymes like lytic enzymes, the extra cellular polysaccharides, endoglucanases and endopolygalacturonases which help in colonization of the bacteria 
further causing the rot and disintegration of the tissue which helps in rapid wilting of infected plants $(13,38)$. The disease is severe in hot humid Southern states as well as in cold high altitude Eastern Himalayan state of Sikkim with a temperature ranges from 28 $30^{\circ} \mathrm{C}$ and $7-22{ }^{0} \mathrm{C}$ respectively.(35)As per Stevenson et.al.2001 optimum temperature for growth of the pathogen is $28-30^{\circ} \mathrm{C}$ except certain races, race 3 strains which are pathogenic to potato are able to grow at lower temperature.(7)In India biovar 3 is more virulent and frequent than biovar 4 due to its vast adaptability towards the varying environmental conditions and adjustability towards the different soil edafic factors. Although Ralstonia slanacearum is a soil borne vascular pathogen, but its survival ability is less in soil and it can survive for a longer period in roots of alternate hosts, undecayed infected plant tissues, volunteers tubers from precedent crops or in deeper layer of soil where they do not confront the antagonism from others soil microorganisms (17). It got the ability to colonize in the rhizospheres of non-host plants (17). Infected rhizome serve as the primary source of the pathogen spread.(34)In field secondary spread occurs through rain splashes and run off water.(34)Pathogen further spread easily through irrigation water, contaminated tools, farm implements, planting materials movement etc.(9) There is high correlation exist between nematode and Ralstonia population. Wounds created by nematode feeding on roots serve as entry for the bacteria, thus presence of root knot nematode and level of bacterial infection are highly correlated with each other.(27)

\section{Disease symptoms and signs}

Different disease symptoms develops after the colonization of Ralstonia solanacearum in the plant vascular system. "Green wilt", in this, symptom occurs early in the disease cycle and yellowing of leaf start. Leaves of infected green ginger roll and curl due to water stress caused by bacteria blocking the water conducting vascular system of the ginger stems. Yellowing of leaves followed by necrotic brown(39). This type of similar yellowing symptom also occur in another disease, known as Fusarium yellows caused by the fungus Fusarium oxysporum f. sp. zingiberi, however in Fusarial wilt rapid wilt don't occur, which normally found in bacterial wilt. (6). Plant dries very rapidly and the foliage becomes yellow brown in 3-4 days. Infected shoots which become soft and completely rotted break off easily from the underground rhizome at the collar region and infected rhizome shows grayish brown discoloration with water soaked central part which becomes soft and rot in advance stage.

Symptoms also include downward curling bending of leaves due to loss of turgidity, growth of adventitious roots in the stems and development of narrow dark stripes in the infected vascular bundles beneath the epidermis due to multiplication of the bacteria in the vascular system that clog the vessels(20,30). The most prominent symptom which distinguish bacterial wilt from other diseases is the exudation of slimy creamy bacterial ooze on the surface of a cut made in the rhizome or on the above ground stem of an infected plant when suspended in a glass or beaker of water.

\section{Genetic based characterization of Ralstonia solanacearum}

Molecular based identification of the pathogen is very useful which based on the selective amplification of the $16 \mathrm{~S}$ ribosomal rRNA gene through Polymerase Chain Reaction (PCR) where the presence of $R$. solanacearum is confirmed by the appearance of a band of targeted amplified DNA on an electrophoresis gel. (14) According to 
Restriction Fragment Length Polymorphism (RFLP) there are two major geographical origins of the strains, American origin consisting of biovars 1 and 2 and Asian origin consisting of biovars 3,4 and 5,which is correlate to the finding of Cook et al., (1989) who assessed the diversity of the pathogen using hypersensitive response and pathogenicity (hrp) genes as probes(2). Kumar et al., (2004) studied that the diversity of $R$. solanacearum causing bacterial wilt on ginger and other hosts in India, the use of REP-PCR (Repetitive Extragenic Palindromic Polymerize chain reaction) and RFLP-PCR (Restriction Fragment Length polymorphismpolymerize chain reaction)as molecular tool could cluster the highly pathogenic isolate in a cluster at $100 \%$ similarity coefficient in conformity with their host origin and biovar (4).

\section{Host Pathogen Interaction Mechanisms}

Genin et al.(1992) studied that the virulence of the pathogen $R$. solanacearum on host species and induction of hypersensitive response in nonhosts is influenced by hrp (hypersensitive response and pathogenicity) gene cluster (31). The $h r p B$ gene encodes for components of the type III secretion pathway(TTSP) which play a key role in pathogenesis of many bacterial pathogens of plants and animals(32). Arlat et al., 1992 found that inactivation of one of the more than 20 hrp genes cease the ability of the pathogen to cause disease and multiply in susceptible plants, as well as loss of the ability to cause hypersensitive defense response in resistant plants(33).In Ralstonia solanacearum type III secretion requires the production of an Hrp pilus. The $h r p Y$ gene encodes this structural protein (31). HrpB and the TTS genes were induced in response to physical contact of bacteria with plant ceIls or cell wall fragments.

\section{Economic importance}

Due to its wide distribution in tropical, subtropical and temperate regions of the world Ralstonia solanacearum causes severe wilt in many crops $(11,12)$.Assefa et al., 2015 and Henok and Kurabachew during 2016 reviewed that Ralstonia solanacearum cause severe yield losses on different crops in different parts of the globe. For instance, 50$100 \%$ of potato in Kenya, $88 \%$ of tomato in Uganda, $70 \%$ of potato in India, $95 \%$ of tobacco in South Carolina and $100 \%$ on Pepper in Ethiopia. Tariku et.al.(2016) also reported that a severe outbreak of ginger wilt disease identified as bacterial wilt caused by $R$. solanacearum with disease incidence of $80-100 \%$ in Ethiopia which is similar to the report done by Habetwold et al., (2015) who reported $80-100 \%$ incidence of bacterial wilt in ginger growing areas $(21,22,28,29)$.In field the range of disease is from $10-40 \%$ but it can also destroy the crop completely(19).In China prevalence of bacterial wilt reduces the yield by $20-30 \% .(18)$.

In conclusion due to its destructive nature Bacterial wilt considered as the major constraint for the cultivation of ginger. Among different biovars, biovar III is found most destructive in India. Among different races, race 4 attacks ginger. Hypersensitive response and pathogenicity (hrp) gene is required for virulence on host species and induction of hypersensitive response in nonhosts. Disease is both soil and water borne and survives between crops on infected seed rhizome. The severity of Ralstonia is influenced by different factors related to environment and soil. Among the different symptoms and signs of the disease rapid wilting and oozing are most prominent. Disease caused by Ralstonia solanacearum which is distributed throughout the world and causes loss in different countries that varies from $10-100 \%$. 


\section{References}

Thomas, K.M., 1941. Detailed Administration Report of the Government Mycologist for the Year 1940-41, pp. 153-154.

Cook D, (1989) Genetic diversity of detection of probes that specify virulence and the hypersensitive response. Molecular Plant-Microbe Interactions 2(3):113.

He LY, Sequeira L, Kelman A (1983) Characteristics of strains of Pseudomonas solanacearum from China. Plant Dis 67(12):1357-1361.

Kumar A, Sarma YR (2004) Characterization of Ralstonia solanacearum causing bacterial wilt in ginger. Indian Phytopathol 57(1):12-17.

Hayward AC (1991) Biology and epidemiology of bacterial wilt caused by Pseudomonas solanacearum. Annu Rev Phytopathol 29(1): 65-87.

Trujillo EE (1963) Fusarium yellows and rhizome rot of common ginger. Phytopathol. 53(11):1370-1371.

Stevenson, W. R., Loria, R., Franc, G. D., and Weingartner, D. P. 2001. Compendium of Potato Diseases, 2nd Edition. APS Press.

Kelman A., 1997. One hundred and one years of research on bacterial wilt. Pages1-5 In: Bacterial Wilt: Molecular and Ecological .

Denny T.P. and Hayward A.C, 2001. Ralstonia solanacearum. pp 151-174 in: Lab Guide for Identification of Plant Pathogenic Bacteria. N. W. Schaad et al. eds. 3rd ed. The American Phytopathological Society, St. Paul, MN, 2001.

Safni I, Cleenwerck I, De Vos P, Fegan M, Sly L, Kappler U (2014) Polyphasic taxonomic revision of the Ralstonia solanacearum species complex: proposal to emend the descriptions of Ralstonia solanacearum and Ralstonia syzygii and reclassify current R.syzygii strains as Ralstonia syzygii subsp. syzygii subsp.nov., $R$. solanacearum phylotype IV strains as Ralstonia syzygii subsp. indonesiensis subsp. nov., banana blood disease bacterium strains as Ralstonia syzygii subsp. Celebesensis subsp. nov. and $R$. solanacearum phylotype I and III strains as Ralstonia pseudosolanacearum sp. nov. Int J Syst Evol Microbiol 64:3087-3103.

Emend the descriptions of Ralstonia solanacearum and Ralstonia syzygii and reclassify current $R$. syzygii strains as Ralstonia syzygii subsp. syzygii subsp. nov., $R$. solanacearum phylotype IV strains as Ralstonia syzygii subsp. indonesiensis subsp. nov., banana blood disease bacterium strains as Ralstonia syzygii subsp. Celebesensis subsp. nov. and $R$. solanacearum phylotype I and III strains as Ralstonia pseudosolanacearum sp. nov. Int J Syst Evol Microbiol 64:3087-3103.

Hayward AC (1994a) Systematics and phylogeny of Pseudomonas solanacearum and related bacteria. In: Hayward AC, Hartman GL (eds) Bacterial wilt: the disease and its causative agent Pseudomonas solanacearum. $\mathrm{CAB}$ International, Wallingford, pp 123-135.

Hayward AC (1994b) The hosts of Pseudomonas solanacearum. In: Hayward AC, Hartman GL (eds) Bacterial wilt: the disease and its causative agent Pseudomonas solanacearum. $\mathrm{CAB}$ International, Wallingford, pp 9-24.

Saile, E., J. A. McGarvey, M. A Schell and T. P. Denny. 1997. Role of Extracellular polysaccharide and endoglucanase in root invasion and colonization of tomato plants by $R$. solanacearum. Phytopathology 87: 1264-1271.

Seal, S. E., Luke, A., Jackson and Daniels, M. J., Use of tRNA consensus primers to 
indicate subgroups of Pseudomonas solanacearum by polymerase chain reaction amplification. Appl. Environ. Microbiol., 1992,58, 3759-3761.

Hayward AC, 1964. Characteristics of Pseudomonas solanacearum. Journal of Applied Bacteriology, 27:265-277

Yabuuchi E, Kosako Y, Yano I, Hotta H, Nishiuchi Y, 1995. Transfer of two Burkholderia and an Alcaligenes species to Ralstonia gen.nov.: Proposal of Ralstonia pickettii (Ralston, Palleroni and Douderoff 1973) comb.nov., Ralstonia solanacearum (Smith 1896) comb. nov. and Ralstonia eutropha (Davis 1969) comb. nov. Microbiology and Immunology, 39:897-904 .

Wenneker M, Verdel MSW, Van Beuningen AR, Derks JHJ and Janse JD (1999) Ralstonia (Pseudomonas) solanacearum race 3 (biovar 2) in surface water and natural weed hosts: first report on stinging nettle (Urtica dioica). European Journal of Plant Pathology 105, 307315.

Liu M., Zhang M., Ji J., Yin F., Zhang Y., Tu Y., et al. (2005). Advances in research bacterial wilt of ginger in China. Chin. Agric. Sci. Bull. 21 337-340.357.

Zhang, G.M., Fan, G.Q., Zhu, H.C., 2001. Study on the pathogen of the ginger wilt disease in Shandong (in Chinese). J. Shandong Agri. Univ. 32 (4), 418-422.

Alvarez, B., E.G. Biosca and M.M. Lopez, 2010. On the Life of Ralstonia solanacearum, a Destructive Bacterial Plant Pathogen. In: Current Research, Technology and Education Topics in Applied Microbiology and Microbial Biotechnology, Mendez-Vilas, A. (Ed.). Formatex Research Center, Badajoz, Spain, pp: 267-279.

Assefa, M., Dawit, W., Lencho, A. and Hunduma, T., 2015. Assessment of wilt intensity and identification of causal fungal and bacterial pathogens on hot pepper (Capsicum annuum L.) in BakoTibbe and Nonno districts of west Shewa zone, Ethiopia. International Journal of Phytopathology, 4 (1), pp.2128.

Habetewold, K., Bekelle, K., Kasahun, S. and Hunduma, T., 2015. Prevalence of Bacterial Wilt of Ginger (Z. Officinal) Caused by Ralstonia solansearum (Smith) in Ethiopia. International Journal of Research Studies in Agricultural Sciences (IJRSAS), 1, pp.14-22.

Mathews, L. Paret1, Asoka S. De Silva1, Richard A. Criley2, and Anne M. Alvarez, 2008. Ralstonia solanacearum Race 4: Risk Assessment for Edible Ginger and Floricultural Ginger Industries in Hawaii.

That, M.M. and Sijam, K., 2010. Roasting solanacearum: The bacterial wilt causal agent. Asian Journal of Plant Sciences, 9(7), p.385.

Smith EF. A bacterial disease of the tomato, eggplant and Irish potato (Bacillus solanacearum nov. sp.). Div. Veg. Phys. and Path. Bul. 12. U. S. Dept. Agr., 1896:1.

Holt, J. G., Krieg, N. R., Sneath, P. H. A., Staley, J. T. \& Williams, 5. T. (editors) (1994). Bergey's Manual of Determinative Bacteriology, 9th edn. Baltimore : Williams \& Wilkins.

P. Deberdta , P. Que'ne'herve' b , A. Darrassea and P. Priora .1999. Increased susceptibility to bacterial wilt in tomatoes by nematode galling and the role of the $\mathrm{Mi}$ gene in resistance to nematodes and bacterial wilt. Plant Pathology (1999) 48, 408-414

Henok Kurabachew, 2016. Bacterial Wilt caused by Ralstonia solanacearum in Ethiopia: Statusa And Management Approaches: A Review. International Journal of Phytopathology 5(3):107119 . 
Tariku hunduma, Kassahun Sadessa and Gezahegne Getaneh,2016. First Report of Ginger (Zingiber officinale) Bacterial Wilt Disease in Ethiopia. Research journal of agriculture and forestry sciences 4(4):5-9.

Kurabachew H. And Ayana G., 2017. Bacterial wilt caused by Ralstonia solanacearum in Ethiopia: status and management approach: a review. International journal of Phytopathology, 5(3), pp.107-119.

Genin S, Gough CL, Zischek C, Boucher CA. 1992. Evidence that the $h r p B$ gene encodes a positive regulator of pathogenicity genes from Pseudomonas solanacearum. Mol Microbiol.; 6:30653076.

Van Gijsegem F, Gough C, Zischek C, Niqueux E, Arlat M, Genin S, Barberis P, German S, Castello P, Boucher C., 1995. The hrp gene locus of Pseudomonas solanacearum, which controls the production of a type III secretion system, encodes eight proteins related to components of the bacterial flagellar biogenesis complex. Mol Microbiol. Mar;15(6): 1095-1114.

Arlat M, Van Gijsegem F, Huet JC, Pernollet JC, Boucher CA. PopA1, a protein which induces a hypersensitivity-like response on specific Petunia genotypes, is secreted via the Hrp pathway of Pseudomonas solanacearum. EMBO J. 1994 Feb 1; 13(3):543-553.

Kampe, A. K., 2018. A Review on Ginger Bacterial Wilt Disease and Its Breeding Approaches Food Science and Quality Management.Vol.80.

Diseases of Ginger Gupta Meenu and Tennyson Jebasingh. Characteristic of Pseudomonas solanacearum, A. C. Hayward, 1964. 265-277. vol-27, Issue2.

Hayward, A. C., Sequeira, L., French, E. R., El-Nashar, H. M., and Nydegger, U. 1992. Tropical variant of biovar 2 of Pseudomonas solanacearum. (Abstr.) Phytopathology 82:608.

\section{How to cite this article:}

Behera, S., P. Sial, G. Biswal and Pradhan, K. 2020. Ralstonia solanacearum the Causal Agent of Ginger Bacterial Wilt- A Review. Int.J.Curr.Microbiol.App.Sci. 9(12): 2709-2715. doi: https://doi.org/10.20546/ijcmas.2020.912.321 